\title{
Innovation, organizational capabilities, and the born-global firm
}

\section{Gary A Knight ${ }^{1}$ and \\ S Tamar Cavusgil ${ }^{2}$}

${ }^{1}$ College of Business, Florida State University, Tallahassee, FL, USA; ${ }^{2}$ Eli Broad Graduate School of Business, Michigan State University, East Lansing, USA

\section{Correspondence:}

Dr GA Knight, College of Business, Florida State University, Tallahassee, FL 323061110, USA.

Tel: +18506441140

Fax: + 18506444098

E-mail: gknight@cob.fsu.edu
Received: 19 November 2002

Revised: 19 October 2003

Accepted: 19 November 2003

Online publication date: 8 January 2004

\begin{abstract}
We investigate born-global firms as early adopters of internationalization - that is, companies that expand into foreign markets and exhibit international business prowess and superior performance, from or near their founding. Our explication highlights the critical role of innovative culture, as well as knowledge and capabilities, in this unique breed of international, entrepreneurial firm. Case studies are analyzed to better understand the early internationalization phenomenon and reveal key orientations and strategies that engender international success among these innovative firms. Case findings are then validated in a survey-based study. Despite the scarce resources typical of young firms, our findings reveal that born-global firms leverage a distinctive mix of orientations and strategies that allow them to succeed in diverse international markets. Findings have important implications for the internationalization of contemporary firms.

Journal of International Business Studies (2004) 35, |24-|4|.

doi: 10. I057/palgrave.jibs.840007|
\end{abstract}

Keywords: early adopters of internationalization; innovation and capabilities; bornglobal firms

Innovation, knowledge, and capabilities have been central themes of research on the strategy and performance of the firm. Companies that operate internationally from an early stage in their development - early adopters of internationalization or 'bornglobal firms' - are emerging in substantial numbers worldwide. Despite the scarce financial, human, and tangible resources that characterize most new businesses, these early internationalizing firms leverage innovativeness, knowledge, and capabilities to achieve considerable foreign market success early in their evolution. Sometimes referred to as international new ventures or global start-ups, they have come of age during the current era of globalization and advanced technologies. Consistent with other scholars (e.g., Autio et al., 2000; Knight and Cavusgil, 1996; Oviatt and McDougall, 1994; Rennie, 1993), we define born globals as business organizations that, from or near their founding, seek superior international business performance from the application of knowledge-based resources to the sale of outputs in multiple countries.

The distinguishing feature of these firms is that their origins are international, as demonstrated by management's global focus and the commitment of specific resources to international activities. In contrast to the traditional pattern of firms that operate in the 
domestic market for many years and gradually evolve into international trade (e.g., Johanson and Vahlne, 1977), these early adopters of internationalization begin with a global view of their markets, and develop the capabilities needed to achieve their international goals at or near the firm's founding. We focus on the phenomenon of early internationalization and the capabilities that born globals leverage for achieving superior performance in international markets.

Reports on the widespread emergence of born globals in numerous nations (e.g., Moen and Servais, 2002; Nikkei Sangyoo Shimbun, 1995; Rennie, 1993) indicate that it is an important phenomenon. These businesses first emerged in countries with small domestic markets, but are now appearing in markedly large numbers throughout the world. The phenomenon appears to be relatively universal, with researchers noting its occurrence in virtually all major trading countries (e.g., Nikkei Sangyoo Shimbun, 1995; OECD, 1997; Simon, 1996). Despite the scarce financial, human, and tangible resources that characterize most new businesses, born globals progress to internationalization relatively rapidly - the period from domestic establishment to initial foreign market entry is often 3 years or less (Autio et al., 2000; McDougall and Oviatt, 2000; OECD, 1997; Rennie, 1993). The smaller size typical of young firms appears to confer a sort of flexibility that provides key benefits for succeeding in foreign markets.

In the external international business environment, early adoption of internationalization is likely driven by two key trends that have substantially reduced the transactions costs of foreign market expansion. The first is the globalization of markets, which involves countless firms in international sourcing, production, and marketing as well as cross-border alliances for product development and distribution. Globalization is associated with increasing homogenization of buyer preferences around the world, which has made international business easier by simplifying product development and positioning in foreign markets. The second trend is technological advances in information and communications technologies, production methods, transportation, and international logistics, which are reducing business transactions costs and facilitating extraordinary growth in international trade. Widespread diffusion of e-mail, the Internet, and related technologies has made internationalization a more viable and costeffective option.
Although these trends facilitate early internationalization, by themselves they are insufficient to explain intriguing processes at work in the firm's internal environment. Despite their current and projected impact, there has been little research that attempts to explain why born globals internationalize early. More significantly, there has been almost no empirical research that examines the factors that drive the superior international performance of these young, highly entrepreneurial firms. In addition, there has been very little empirical research aimed at uncovering the actual bundles of capabilities that characterize truly innovative firms, as well as the causal link between the possession of particular types of knowledge, organizational routines, and superior performance (Lewin and Massini, 2003; Massini et al., 2003).

Accordingly, a substantive investigation in this area is overdue. The study reported here explores the role of innovative culture and organizational capabilities in the early adoption of internationalization and subsequent international performance in the born-global firm. We intend to make several contributions. First, we investigate the phenomenon of early internationalization among a unique breed of international organization. Second, we highlight the importance of several key organizational capabilities that engender international success in born globals - research that has implications not only for these firms but also for internationalizing smaller firms in general. Third, and more specifically, we examine the critical linkages among entrepreneurial orientation, marketing orientation, and other key organizational capabilities in born-global international success. In the process, we extend the innovation literature by linking innovation to the phenomenon of early adoption of internationalization.

In the next section, we offer a conceptual framework that provides the rationale for the emergence of early adopters of internationalization in the current era. We then summarize the research methods used in this study. Specifically, we conduct a series of exploratory case studies on born-global firms, which lead to a set of hypotheses. We then assess these hypotheses in a confirmatory, surveybased study. Finally, we report on empirical findings, providing an overview and substantive discussion.

\section{Conceptual foundations}

The ability to internationalize early and succeed in foreign markets is a function of the internal 
capabilities of the firm (Autio et al., 2000; McDougall et al., 1994; Zahra et al., 2000). The importance of internal capabilities is rooted in evolutionary economics (Nelson and Winter, 1982), wherein innovation processes are explicitly described. The evolutionary economics view implies that the superior ability of certain firms to sustain innovation and, as a result, create new knowledge leads to the development of organizational capabilities, consisting of critical competences and embedded routines. These firm resources in turn lead to superior performance, particularly in highly competitive or challenging environments (Nelson and Winter, 1982).

Innovation results from two major sources: (1) internal R\&D that draws on the firm's accumulated knowledge, and (2) imitation of the innovations of other firms (Lewin and Massini, 2003; Massini et al., 2003; Nelson and Winter, 1982). In addition to introducing new goods and methods of production, R\&D also supports the opening of new markets and reinvention of the firm's operations to serve those markets optimally (Nelson and Winter, 1982; Schumpeter, 1934). Innovation is particularly the domain of entrepreneurs, whose function is:

to reform or revolutionize the pattern of production by exploiting an invention or, more generally, an untried technological possibility for producing a new commodity or producing an old one in a new way, by opening up... a new outlet for products

and so forth (Schumpeter, 1942: 132). Firms' innovative culture, combined with appropriate accumulated knowledge stocks, engenders the development or improvement of products and new methods for doing business (Dosi, 1988; Nelson and Winter, 1982). Internationalization, or new entry into markets overseas, is an innovative act (Casson, 2000; Schumpeter, 1939; Simmonds and Smith, 1968), and born-global firms are particularly innovative in this regard.

The resource-based view (RBV) (e.g., Grant, 1996a; Penrose, 1959; Rumelt, 1984; Teece and Pisano, 1994; Wernerfelt, 1984) helps to explain how, in the context of an innovative culture, knowledge and resultant organizational capabilities are developed and leveraged by enterprising firms. Differential endowment of resources is an important determinant of organizational capabilities and performance (Barney, 1991; Grant, 1996a; Teece and Pisano, 1994; Wernerfelt, 1984). Foundational resources are particularly important in turbulent business environments because they are a more stable basis for strategy formulation (Grant, 1996a; Prahalad and Hamel, 1990). Knowledge is the most important resource, and the integration of individuals' specialized knowledge is the essence of organizational capabilities (Conner and Prahalad, 1996; Dierickx and Cool, 1989; Grant, 1996a; Leonard-Barton, 1992; Nelson and Winter, 1982; Solow, 1957).

In international business, knowledge provides particular advantages that facilitate foreign market entry and operations (e.g., Kogut and Zander, 1993). Knowledge is used here to refer to the capacity of the firm to apprehend and use relationships among informational factors to achieve intended ends (Autio et al., 2000). Gross output and overall organizational performance are directly traceable to increases in stocks of organizational knowledge (Nelson and Winter, 1982; Solow, 1957). The integration of specialist knowledge hinges on the nature and quality of the firm's organizational routines, which involve continuous conversion of, especially, tacit knowledge (Polanyi, 1966) into business activities that create value for customers. Tacit knowledge is embedded in individuals and cannot be expressed explicitly or codified in written form (Nonaka, 1994).

In this regard, the most important knowledge resources are unique, inimitable, and immobile, reflecting the distinctive pathways of each individual firm (Dierickx and Cool, 1989; Grant, 1991, 1996a). Uniqueness facilitates profitable pricing that minimizes the need to consider competitors' offerings, inimitability helps ensure that profits will not be competed away, and immobility reduces the threat that proprietary knowledge will be disseminated to rival firms (Nelson and Winter, 1982; Teece and Pisano, 1994). Ultimately, the firm accumulates firm-specific knowledge internally (Barney, 1991; Dierickx and Cool, 1989; Teece et al., 1997). Organizational knowledge derived from multiple individual sources is greater than the sum of its parts, and becomes a key strategic asset (Nelson and Winter, 1982). It is reinforced in all the activities of the firm and becomes increasingly embedded in its routines (Autio et al., 2000).

The idiosyncratic knowledge base acquired by following unique pathways gives rise to organizational capabilities (Dierickx and Cool, 1989; Nelson and Winter, 1982; Nonaka, 1994; Teece et al., 1997). Organizational capabilities reflect the ability of the firm to perform repeatedly, or 'replicate', productive tasks that relate to the firm's capacity to create 
value through effecting the transformation of inputs into outputs (Nelson and Winter, 1982; Teece and Pisano, 1994). Capabilities emerge via the integration of specialist knowledge across a number of individuals, and are associated with the development of organizational competences and routines (Grant, 1991; Teece and Pisano, 1994). Competences are those knowledge-intensive, performance-enhancing business activities in which the firm is particularly skilled (Teece et al., 1997). Routines consist of regular and consistently practiced patterns of individual and business behaviors that institutionalize individual or organizational knowledge about the firm's ongoing, rent-generating activities (Dosi, 1988; Nelson and Winter, 1982; Teece and Pisano, 1994). Routinization of organizational activities embeds capabilities into organizational memory, engendering a unique configuration of firm resources.

Organizational capabilities are the main source of the firm's performance advantages (e.g., Grant, 1991). Capabilities have two major aspects: (1) the shifting character of the business environment; and (2) strategic management in appropriately adapting, integrating, and re-configuring knowledgebased capabilities toward the changing environment. Ideally, capabilities are 'dynamic', reflecting the ability of managers to renew the firm's competences so as to achieve congruence with the changing business environment (Teece et al., 1997). Replication of organizational capabilities involves transferring or re-deploying capabilities from one organizational or business environmental setting to another, so as to extend the firm's performance into new markets, new product categories, and new ways of doing business (Nelson and Winter, 1982; Teece et al., 1997).

\section{Organizational capabilities and the born-global firm}

Innovating firms develop their own unique knowledge and resultant capabilities that engender organizational performance. New product-market development in young, innovative firms is fluid and dynamic, with ongoing market expansion and redefinition resulting in frequent competitive improvements to the firm's offerings and routines (Utterback and Abernathy, 1975). Whereas larger, long-established firms usually experience substantial bureaucratization that hinders their innovative activities, smaller or younger firms are more flexible, less bureaucratic, and generally enjoy internal conditions that encourage innovativeness (e.g., Lewin and Massini, 2003; Penrose, 1959; Schumpeter, 1942).

Lewin and Massini (2003) point to various empirical studies on the effects of firm size and age on innovation. The studies conclude that there is a positive relationship between firm size and R\&D activities, but innovation capabilities appear to be less than proportional to size, and therefore $\mathrm{R} \& \mathrm{D}$ productivity declines with size, and also therefore with age. The flexibility of young and agile firms enhances the ability to transform product and process innovations into business activities that support superior business performance (Lewin and Massini, 2003).

We conjecture that young firms with a strong innovation culture and a proclivity to pursue international markets tend to internationalize earlier than internationally oriented young firms that lack an innovation culture. This same innovation culture also should facilitate the acquisition of knowledge, leading to capabilities that drive organizational performance. Our research suggests that born globals are inherently entrepreneurial and innovative firms that possess these types of characteristics. These businesses display a specific pattern of knowledge and capabilities that engenders early internationalization and sustainable, superior performance in foreign markets.

The youth of these firms is interlinked with entrepreneurial and innovative approaches to doing business. Being young, born globals tend to lack substantial financial and human resources, as well as plant, equipment, and other physical resources. It is these tangible resources that older firms typically have relied upon to drive their performance in foreign markets. In contrast, born globals leverage a collection of fundamental intangible knowledge-based capabilities in the cultivation of foreign markets early in their evolution.

Superior performance is an outcome of the firm's entrepreneurial and managerial knowledge (Autio et al., 2000; Penrose, 1959). Knowledge about international markets and operations, as well as the efficiency with which such knowledge is acquired, is a critical determinant of superior international performance in entrepreneurial firms (Autio et al., 2000). Lewin and Massini (2003) contend that firms with superior innovation and knowledge-creation processes have more sophisticated, more highly developed and elaborated knowledge-creation routines and learning regimes. Consistent with innovation scholars (e.g., Lewin and Massini, 2003; Nelson and Winter, 1982), we 
conjecture that born globals undertake $R \& D$ projects that lead to entering new foreign markets, or they observe other early adopters of internationalization entering foreign markets and imitate such behaviors accordingly.

Capabilities-based resources are especially important to born globals, typically poor in tangible resources, because they deal with diverse environments across numerous foreign markets (Luo, 2000). Possession of such capabilities helps firms to attenuate their liabilities of foreignness and newness (Oviatt and McDougall, 1994). Foreignness reflects the unfamiliarity and strangeness that firms experience in foreign markets. Newness refers both to the state of being a young or new firm and to the entering of new markets - both characteristics of born-global firms. The ability to consistently replicate the firm's capabilities across numerous and varied markets produces value for born globals by supporting, especially, international expansion (Teece et al., 1997).

\section{Organizational routines and administrative heritage}

A key dimension of born-global firms is that they appear to lack the deeply rooted administrative heritage (Collis, 1991; Miller and Friesen, 1984) of long-established businesses. Well-established firms typically must unlearn routines rooted in domestic operations before new, internationally oriented routines can be learned. Unlearning embedded routines becomes more difficult as firms get older, because new knowledge that leads to new routines tends to conflict with existing operations and management's embedded mental models (Autio et al., 2000; Barkema and Vermeulen, 1998). Wellestablished firms have systematized routines that are costly to change and limit the ability of the firm to innovate (Utterback and Abernathy, 1975). The older firm's previous investments and its repertoire of organizational routines constrain its future behavior (Leonard-Barton, 1992; Teece and Pisano, 1994). Bounded rationality and embedded 'hierarchies' (Grant, 1991) of routines inhibit the ability of well-established firms to adopt new technological solutions, leading to an emphasis on developing knowledge and routines closely related to or adjoining their existing knowledge and routines, but which may be sub-optimal in light of evolving or varying environmental circumstances.

In contrast, from their earliest days, the innovative culture of born-global firms gives rise to specific capabilities suitable for success in foreign markets. Their entrepreneurial orientation is associated with an innovative and proactive approach to internationalization. Organizational learning theory suggests that the development of new knowledge occurs best under conditions in which there are little or no existing organizational routines to unlearn (Autio et al., 2000; Cohen and Levinthal, 1990). This implies that young firms may be better equipped to acquire the requisite knowledge about international business. Escalating internationalization facilitates further learning opportunities that benefit their performance because of the range of unique environments and competitive situations to which these firms are exposed. Thus early internationalization may confer substantial benefits in terms of knowledge acquisition about international markets and how to succeed there. In the next section, we describe the specific capabilities that drive the international performance of born-global firms.

\section{Delineation of key capabilities and linkages}

As the widespread emergence of born globals is relatively recent, little empirical work has been attempted on this topic. Accordingly, a two-phase research design was adopted that began with qualitative interviews to develop a broader understanding of these organizations and to uncover key constructs and linkages. In the second phase, we conducted survey-based research on a large sample of born-global firms to validate findings from the qualitative phase. In-depth interviews were conducted with 33 professionals. These included senior managers at 24 early internationalizing firms, six scholars who have investigated born globals, and three international trade experts who are key observers of global business trends. Most of the interviewed firms were founded after 1985, were selling half or more of their total sales abroad, and had ventured abroad within 3 years of founding. The interviews typically lasted about $45 \mathrm{~min}$ and were analyzed and organized according to patterns of consistent themes of firm culture, strategy, and performance. In all, 18 of the businesses marketed various industrial products, and the remaining six sold consumer goods. The average firm had $\$ 52$ million in annual sales and 296 employees. The capabilities and associated relationships that emerged from these interviews are discussed below.

In general, the qualitative phase of the study revealed that born globals are likely to be formed by entrepreneurs who pursue foreign ventures with a strong marketing orientation. They tend to leverage 


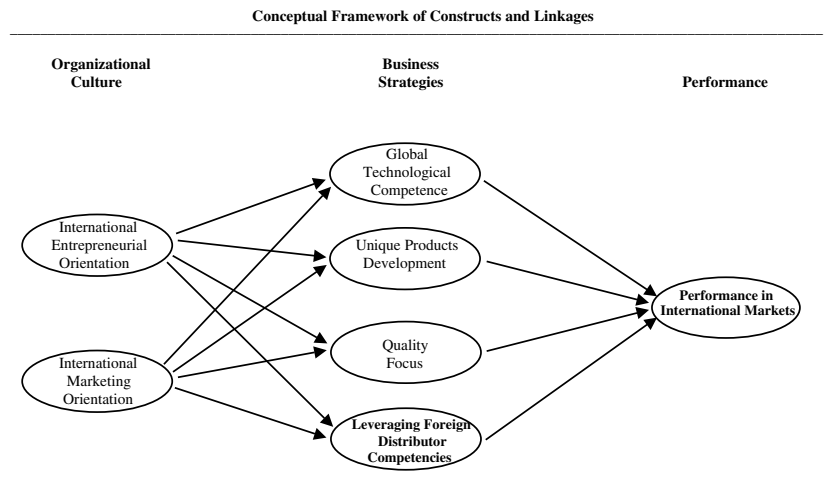

Figure 1 Conceptual framework of constructs and linkages.

technological prowess, relatively unique products, and a strong quality focus to sell their offerings via independent distributors in markets worldwide. Among operational attributes, entrepreneurial culture, marketing skills, superior and distinctively positioned products, and leveraging strong distributors, all emerged as important capabilities for born globals to position themselves in foreign markets.

Figure 1 highlights the specific constructs and relationships that emerged from the qualitative research. Ultimately, the interviewed firms were seeking superior performance in international markets, which is defined as the extent to which financial and other goals are achieved as a function of business strategies. Performance comprises expectations about the achievement of these objectives in addition to more conventional economic goals, such as profitability, sales growth, market share, and general international success. Each firm's unique base of resource-derived capabilities drives its international performance. The performance antecedents and associated linkages proposed in Figure 1 are elaborated next.

\section{Organizational culture}

Within the framework of evolutionary economics, specific ways of doing business emerge from the core capabilities founded on the knowledge and skills embodied in organizational employees, and codified and structured into a base of tacit information and routines. Innovative firms devise particular types of knowledge and capabilities that become embedded in the organization's culture. In our case studies, the great majority of interviewed managers at born-global firms spoke about the importance of being internationally oriented as well as entrepreneurial and innovative in the pursuit of foreign markets. They also emphasized the importance of developing and applying a strong marketing prowess abroad. Based on these findings, we conceive that the most important organizational culture attributes in born-global firms are what we term international entrepreneurial orientation and international marketing orientation.

Having an international entrepreneurial orientation implies that these firms make the leap into international markets because of unique entrepreneurial competences and outlook (e.g., Autio et al., 2000; McDougall et al., 1994). The interviewed born globals seem to possess a distinctive entrepreneurial orientation that, when combined with other resources and capabilities such as strong marketing skills, allows them to see and exploit opportunities in foreign markets. International entrepreneurial orientation reflects the firm's overall innovativeness and proactiveness in the pursuit of international markets. It is associated with innovativeness, managerial vision, and proactive competitive posture (Covin and Slevin, 1989; Dess et al., 1997; Lumpkin and Dess, 1996; Miller and Friesen, 1984). These activities are consistent with what Lumpkin and Dess (1996) term 'new entry,' the 'central idea underlying the concept of entrepreneurship' ( $p$ 136). For born globals, it implies the entering of new (that is, international) markets with new or established goods. A posture that is innovative, visionary, and proactive may be necessary amongst a class of firms that, in the face of relatively limited resources, takes the initiative to pursue new opportunities in complex markets, typically fraught with uncertainty and risk.

Dess et al. (1997) point to a substantial literature that emphasizes the inherent value in entrepreneurial behavior and a linkage between this behavior and desired organizational outcomes. Possession of an entrepreneurial orientation gives rise to certain 'processes, practices, and decisionmaking activities' associated with successful entry into new markets (Lumpkin and Dess, 1996). Whereas unbridled risk seeking may engender inferior performance, having an entrepreneurial orientation in diverse foreign environments tends to support the realization of key strategic initiatives that augment international success. Accordingly, international entrepreneurial orientation should be instrumental to the development and enactment of key organizational routines in born-global firms.

The critical role of marketing prowess overseas was also strongly emphasized by virtually all interviewees in the case studies. We conceptualize 
this as international marketing orientation, which refers to a managerial mindset that emphasizes the creation of value, via key marketing elements, for foreign customers (Cavusgil and Zou, 1994). Market orientation, marketing competence, and other marketing-related activities engender superior organizational performance (e.g., Albaum and Peterson, 1984; Cavusgil et al., 1993; McKee et al., 1992; Slater and Narver, 1992). Within their markets, marketing-oriented firms seek to offer products and services whose value buyers perceive to exceed the expected value of alternative offerings. The urge to continuously provide superior buyer value and attain superior performance drives the firm to create and maintain a business culture that fosters the requisite business behaviors. Globalization is facilitating the emergence of customers who are better organized, have more information, and are generally more demanding. A heightened focus on the customer is driven by a more competitive international marketplace, rapid changes in technology that have shortened product life cycles, and the mediocre financial performance of many firms. A marketing orientation provides the foundation from which the firm interacts with diverse foreign markets. Managers with this orientation create specific marketing-related strategies aimed at overcoming these challenges and maximizing performance.

\section{Business strategies}

The RBV suggests a holistic view of the firm, in which the coordinated deployment of resources and capabilities provides the foundation for creating, producing, and marketing products (Young et al., 2000). Along these lines, the case studies suggest that born globals are highly innovative firms whose possession of the foundational capabilities of international entrepreneurial orientation and international marketing orientation engender the development of a specific collection of organizational strategies. The most important business strategies employed by born-global firms that emerged in our investigation are global technological competence, unique products development, quality focus, and leveraging of foreign distributor competences. These are described next.

Most interviewed firms exhibited strong technological capabilities in their respective product or industry categories. Global technological competence refers to the firm's technological ability relative to cohort firms in its industry. It facilitates the creation of superior products and the improvement of existing products, as well as greater effectiveness and efficiency in production processes. Advances in production technologies facilitate low-cost, smallscale manufacturing that enable smaller-scale firms to efficiently serve the specialized needs of market niches worldwide. Moreover, global technological leaders tend to leverage information and communications technologies to interact more efficiently with channel members and customers, and to obtain various other benefits (Clark, 1987; Zahra et al., 2000).

Emphasis on developing new technologies is a natural routine for innovative, entrepreneurial firms (Nelson and Winter, 1982; Schumpeter, 1934). Entrepreneurship derives from 'the capacity of small firms to leverage resources and transform existing markets through innovation' (Steensma et al., 2000: 951). This basic innovativeness gives rise to new ideas and creative processes, reflecting a willingness to depart from existing technologies (Lumpkin and Dess, 1996). Entrepreneurial firms continually seek to create products and operating methods that improve organizational performance (e.g., Lumpkin and Dess, 1996; Miller and Friesen, 1984; Mintzberg, 1973; Zahra et al., 2000). Overall, innovation is a critical entrepreneurial process for firm performance in competitive international markets (e.g., Kotabe, 1990; Miller and Friesen, 1984; Steensma et al., 2000; Zahra et al., 2000).

International marketing orientation can also foster global technological competence. Firms leverage technology to innovate in the creation and improvement of products, as well as the adaptation of products for foreign markets. Information and communication technologies facilitate learning about customers and competitors, efficient channel interaction, and other benefits. Overall, as with most companies, technology facilitates the marketing process in born-global firms. The above discussion leads to our first hypothesis, which, consistent with Figure 1, relates international entrepreneurial and marketing orientations to global technological competence:

H1: In the born-global firm, global technological competence is a function of (a) international entrepreneurial orientation and (b) international marketing orientation.

In addition to technology, the interviewed firms also emphasized having relatively unique products. The ability to develop unique products derives from the innovative and knowledge-intensive capabilities of these firms. Unique products development 
reflects the creation of distinctive products, and is akin to differentiation strategy, which involves creating customer loyalty by uniquely meeting a particular need. Marketing scholars have long recognized the inherent value in providing unique offerings, so as to differentiate the firm from rivals (e.g., Cavusgil et al., 1993; Smith, 1956). A priori, valuable unique products should allow resourceconstrained firms to readily enter foreign markets and may be particularly appropriate to born-global firms, which tend to operate in niche markets and hold relatively specialized resources. The approach is typically associated with innovative product features, excellent customer service, or patented know-how - all factors that distinguish the firm from its competitors (Miles and Snow, 1978; Miller and Friesen, 1984; Porter, 1980).

Knowledge developed within innovative processes provides the capabilities needed for new technology development, and is perhaps the key resource that born globals use to develop unique products and overcome the indigenous advantages enjoyed by local firms (Oviatt and McDougall, 1994). To the extent that the knowledge used to develop a unique product is tacit or imperfectly imitable (Barney, 1991; Grant, 1996b; Autio et al., 2000), individual firms are able to keep such knowledge proprietary. The knowledge intensity of young, entrepreneurial firms is positively related to their growth in international sales (Autio et al., 2000; Zahra et al., 2000). Knowledge and the firm's technological competence should also facilitate the development of unique products. Knowledge that fosters unique products development also allows born globals to serve specific markets well, giving rise to increased market share and sales growth. Offering unique products, at least to the extent that buyers' special needs are served and direct competitive rivalries are minimized, supports superior international performance.

Generally, internationally entrepreneurial firms proactively seek success in foreign markets. However, owing to their youth and relatively smaller size, born globals minimize direct competition with larger or more established rivals. Born globals that aggressively pursue international success develop differentiated offerings and target them at niche markets overseas. This approach is appropriate for maximizing share and other performance goals in a competitive international marketplace typically dominated by larger, resource-endowed firms. Moreover, differentiation strategy and the creation of unique products are marketing-based strategies.
Smaller, resource-constrained firms that are strongly marketing-oriented will be more inclined to undertake strategies that differentiate their offerings from those of rivals, thereby facilitating superior performance. These ideas are evidence of the next hypothesis:

H2: In the born-global firm, unique products development is a function of (a) international entrepreneurial orientation and (b) international marketing orientation.

Virtually all of the executives interviewed emphasized the importance of superior quality in the products that they developed. Born globals appear to leverage their innovativeness and knowledge base to develop offerings of relatively superior quality. Quality focus reflects efforts to develop products that meet or exceed customer expectations with respect to features and performance. It represents a broad-based concept that potentially encompasses the full range of the firm's valueadding activities (Aaker and Jacobson, 1994; McGuinness et al., 1991; Mohr-Jackson, 1998). Consumers favor superior quality products, and are willing to pay higher prices for them. Producers and consumers in globalizing environments may be more inclined to benchmark their quality standards against those of foreign-based firms. The new awareness resulting from such comparisons pressures companies to improve (McGuinness et al., 1991). Moreover, emphasis on quality entails innovative processes and provides a means to differentiate goods from those of competitors (Porter, 1980). Quality has been linked to improved performance in domestic (e.g., Aaker and Jacobson, 1994; Buzzell and Gale, 1987; Mohr-Jackson, 1998) and international markets (e.g., McGuinness et al., 1991; Szymanski et al., 1993). To the extent that superior quality reduces rework and service costs while enhancing value, market share and profits can rise, and thus it is likely to be associated with superior performance in born globals (Buzzell and Gale, 1987; Deming, 1982; Szymanski et al., 1993).

Entrepreneurial orientation gives rise to innovative processes and practices intended to maximize organizational success in new markets (Lumpkin and Dess, 1996). Having an international entrepreneurial orientation engenders the development of key strategies, of which our research reveals quality focus is a key component. As an important marketing strategy, firms with a strong international marketing orientation are also likely to promote a quality focus. Providing valuable, quality-enhanced 
offerings is one of the approaches closely associated with strong marketing capabilities (e.g., Szymanski et al., 1993). Accordingly:

H3: In the born-global firm, quality focus is a function of (a) international entrepreneurial orientation and (b) international marketing orientation.

Internationalizing firms must choose appropriate entry modes. Compared with traditional multinational enterprises, young resource-poor firms tend to favor exporting as their primary entry mode. Exporting offers a high degree of international business flexibility - the ability to change systems and approaches quickly and cost-effectively - a critical consideration in evolving foreign markets (Buckley and Casson, 1998). Indeed, all of the interviewed firms were exporters and tended to rely on independent intermediaries to distribute their products abroad. Foreign export intermediaries typically possess strong market knowledge and particular competences, and perform valuable functions in foreign markets (Peng and York, 2001; Rosson and Ford, 1982).

Although born globals possess various superior capabilities on their own, they must rely to some extent on the capabilities of facilitators in foreign markets to deal with the range of complexities found there. Leveraging foreign distributor competences refers to the tendency of born globals to rely on foreign independent distributors and those distributors' specific competences to maximize performance outcomes associated with downstream business activities abroad. The uncertainty, risk, and unique challenges present in foreign markets can be overcome by leveraging the localized market knowledge and competences of foreign intermediaries (Bowersox and Cooper, 1992; Rosson and Ford, 1982).

The flexibility afforded through judicious use of foreign distributors enables entrepreneurial firms to respond rapidly to evolving customer needs, competitor actions, and shifting environmental contingencies. Entrepreneurial firms are given to active exploration of new business opportunities in foreign markets, and the use of competent local intermediaries facilitates this task. Aggressive top managers eager for international success will tend to leverage competent foreign distributors. Strongly marketing-oriented firms will also tend to seek competent foreign intermediaries because, in international markets, strong distribution capabilities facilitate superior promotion, customer relation- ship management, and other downstream marketing activities. Siguaw et al. (1998) found that marketing-oriented attitudes in suppliers are associated with the presence of such attitudes in distributors. In general, the more skillful international marketing is emphasized, the greater the importance that is accorded to the foreign distribution channel (Cavusgil et al., 1993; Mortanges and Vossen, 1999). Accordingly, we hypothesize that:

H4: In the born-global firm, leveraging foreign distributor competences is a function of (a) international entrepreneurial orientation and (b) international marketing orientation.

As elaborated earlier and in Figure 1, the above knowledge- and capabilities-based business strategies are expected to engender superior international performance in born-global firms. To summarize, global technological competence is a critical source of new products and business methods, and has the potential to foster information technology and e-commerce proficiency, all of which can positively influence born-global international performance (e.g., Kotabe, 1990; Zahra et al., 2000). Unique product development yields differentiation strategy benefits (e.g., Porter, 1980; Smith, 1956), which can allow born globals to serve niche markets more capably and minimize harmful interaction with competitors, giving rise to increased sales and other performance gains. Quality focus implies a system of firm resources specifically devoted to creating superior offerings, prompting enhanced customer satisfaction and differentiation benefits, leading to increased customer loyalty and improved performance (e.g., Buzzell and Gale, 1987; Deming, 1982). Leveraging foreign distributor competences is markedly critical to born-global international success because, to the extent that these firms emphasize external marketbased entry modes, skillful foreign intermediaries can perform a range of downstream marketing and other activities that enhance international performance. (e.g., Rosson and Ford, 1982; Bowersox and Cooper, 1992). The above reasoning leads to the final hypothesis:

H5: In the born-global firm, superior performance in international markets is primarily a function of (a) global technological competence, (b) unique products development; (c) quality focus, and (d) leveraging foreign distributor competences. 
Lastly, it should be noted that foreign distributor competences are likely to drive, and be supported by, the firm's quality focus. This is because quality products are easier for foreign distributors to sell, and foreign distributors can also enhance product quality by providing superior after-sales service, intensive distribution, and so forth. Similarly, to the extent that foreign distributors seek to differentiate themselves and/or focus on target markets, these tasks also can be facilitated when handling relatively unique goods. The hypotheses described above are tested next, by means of a mail survey study.

\section{Method}

To provide empirical support for the conceptual framework proposed above, we conducted a crossindustry field survey to collect primary data. The survey instrument was developed in several stages, following appropriate procedures (e.g., Fowler, 1988; Gerbing and Anderson, 1988; Joreskog et al., 2000; Nunnally, 1978) and based on insights gained from the interviews and available literature. The literature was searched to obtain information on the key constructs and scales appropriate for measuring them. Seven-point Likert scales were used to minimize executive response time and effort (Fowler, 1988).

For all constructs except international entrepreneurial orientation and international marketing orientation, the identified unit of analysis was the firm's main export venture to its primary export market. The unit of analysis for the organizational culture constructs was the general firm level. Exporting was emphasized because case studies and other research (e.g., OECD, 1997) suggest it is the most common entry mode of born-global firms. Information on the measurement scales is provided in the Appendix. The scale for international entrepreneurial orientation was based on the scale devised by Khandwalla (1977) and Covin and Slevin (1989). A version of it was used most recently by Steensma et al. (2000). The international marketing orientation scale was created for the study based on research by McKee et al. (1992). It asks subjects about their skillfulness in marketing management, product adaptation, pricing, advertising, distribution, and other marketing functions, relative to competitors. The global technological competence scale was created for the study and asks subjects about their position relative to competitors with respect to technology, technological innovativeness, and so forth. The scale for unique products development was derived from research by several scholars (e.g., Miller, 1988; Porter, 1980; Roth and Morrison, 1992). It asks respondents about the relative uniqueness of the firm's main export product, its design, technology, and performance. The quality focus scale is based primarily on the work of Buzzell and Gale (1987) and asks subjects about product quality as well as the extent to which the product meets or exceeds customer expectations with respect to performance and customer service. The scale for leveraging foreign distributor competences was developed for the study, but based partially on McKee et al. (1992). It asks about the extent to which respondent expectations have been satisfied with respect to distributor performance of various marketing-related functions, logistical arrangements, after-sales service, and related activities. Lastly, the scale for performance in international markets was obtained from Cavusgil and Zou (1994).

Once a draft questionnaire was completed, it was circulated among four international business scholars, who provided commentary that led to further refinement of the instrument. Next, a pilot study was conducted among 82 small exporting firms to refine the questionnaire. Firms were identified primarily via two databases: Directory of United States Exporters (Journal of Commerce) and CorpTech Directory of Technology Companies. The final questionnaire was targeted to a random sample of 900 manufacturing firms across the United States, founded in 1980 or later, and exporting at least $25 \%$ of total production. The $25 \%$ cut-off, although somewhat arbitrary, was established in light of the exploratory goals of the research and the attendant need to study exemplary firms. It is more restrictive than the criteria, ranging from 5 to $10 \%$, used in previous studies on early adopters of internationalization (Zahra et al., 2000). Except for these criteria, the surveyed businesses were selected at random from the above commercial databases.

Following a three-wave mailing, 203 usable surveys were returned, reflecting a response rate of about 23\%. To assess non-response bias we compared key variables in surveys from a sample of the earliest responding to those of a sample of the latest responding firms (Armstrong and Overton, 1977). In a second test, we compared randomly chosen samples of responding and non-responding firms. Compared variables included number of employees, founding year, total sales, product category, return on investment, sales growth, and market share in main export market. No significant 
differences $(P<0.05)$ were found in these tests and thus non-response bias is not expected to significantly affect study results. Following data collection, measures were subjected to a purification process to verify reliability and validity (Gerbing and Anderson, 1988; Joreskog and Sorbom, 1997; Joreskog et al., 2000).

Initially, exploratory factor analysis was conducted to identify and eliminate potentially troublesome items. Confirmatory factor analysis (CFA) was then conducted in LISREL8 (Joreskog and Sorbom, 1997; Joreskog et al., 2000) to estimate a single measurement model representing relations among all constructs and associated items. The model achieved adequate fit with $\mathrm{CFI}=0.92$, $\mathrm{NNFI}=0.91, \quad$ DELTA2 $=0.92, \quad \mathrm{RNI}=0.92, \quad$ and RMSEA $=0.046$ (Gerbing and Anderson, 1992; Joreskog and Sorbom, 1997; Joreskog et al., 2000). A second CFA model was estimated, using data from a separate sample of general exporting firms $(n=134)$ collected for another study, using the same scales. Results for this model also were satisfactory $(\mathrm{CFI}=0.90, \mathrm{NNFI}=0.89$, DELTA $2=0.90, \mathrm{RNI}=0.90$, and RMSEA $=0.14$ ). All standardized coefficient loadings in this model were significant at $P<0.01$.

Composite reliability was calculated using the procedures outlined by Fornell and Larcker (1981). The specific formula is

$$
\mathrm{CR}_{\eta}=\frac{\left(\Sigma \lambda_{\gamma_{i}}\right)^{2}}{\left(\Sigma \lambda_{\gamma_{i}}\right)^{2}+\Sigma \varepsilon_{i}}
$$

where $\mathrm{CR}_{\eta}$ is the composite reliability for scale $\eta, \lambda_{\gamma_{i}}$ is the standardized loading for scale item $\gamma_{i}$, and $\varepsilon_{i}$ is the measurement error for scale item $\gamma_{i}$. In the main study, the $\mathrm{CR}_{\eta}$ values ranged from 0.72 to 0.92 , exceeding acceptable standards for exploratory research (Fornell and Larcker, 1981; Nunnally, 1978). In the LISREL measurement model on the main data, all standardized coefficients were sig- nificant at $P<0.01$, confirming convergent validity. Composite reliability values and standardized coefficient loadings for all construct items from CFA analyses on the main data set are reported in the Appendix. Table 1 presents information on construct means, standard deviations, and Pearson's correlation coefficients among the constructs. LISREL modification indices revealed no substantive cross-loadings of questionnaire items intended to measure specific constructs. We also compared all possible pairs of construct measures ( 21 in all) by constraining and freeing the associated phi coefficients $(\phi)$ (Fornell and Larker, 1981). The change in $\chi_{(1)}^{2}$ in these tests ranged from 54 to 343 , greatly exceeding the critical value 3.84 in each case. These tests confirmed the discriminant validity of all construct measures. In all, the study scales were found to be reliable and valid.

\section{Data analysis}

Respondent firms represent a range of industries that manufacture various products, such as wastewater treatment systems, medical devices, alarm systems, coiled steel tubing, computer software, textile printing blankets, and oil field surfactants. The average firm had 190 employees and generated $\$ 32$ million in total sales. On average, foreign customers accounted for $41 \%$ of total sales, with firms targeting some 20 countries at the median. The median firm began selling internationally within 2 years of founding.

Table 2 portrays results of the tests to assess hypotheses on born-global firms. The data were analyzed in LISREL8, using path analysis. Results provide strong evidence that global technological competence is significantly $(P<0.01)$ a function of international entrepreneurial orientation, partially supporting hypothesis H1. However, the posited relationship between international marketing

Table 1 Construct means, standard deviations, and Pearson's correlation coefficients

\begin{tabular}{|c|c|c|c|c|c|c|c|c|c|}
\hline Construct & Mean & Standard deviation & (1) & (2) & (3) & (4) & (5) & (6) & (7) \\
\hline (1) International entrepreneurial orientation & 5.13 & 0.98 & 1.00 & & & & & & \\
\hline (2) International marketing orientation & 4.64 & 0.84 & 0.36 & 1.00 & & & & & \\
\hline (3) Global Technological Competence & 5.12 & 1.02 & 0.33 & 0.23 & 1.00 & & & & \\
\hline (4) Unique products development & 4.84 & 0.98 & 0.27 & 0.30 & 0.44 & 1.00 & & & \\
\hline (5) Quality focus & 5.75 & 0.70 & 0.36 & 0.44 & 0.19 & 0.31 & 1.00 & & \\
\hline (6) Leveraging foreign distributor competences & 4.32 & 0.88 & 0.19 & 0.29 & 0.16 & 0.17 & 0.29 & 1.00 & \\
\hline (7) Performance in international markets & 4.58 & 0.96 & 0.32 & 0.49 & 0.36 & 0.35 & 0.44 & 0.32 & 1.00 \\
\hline
\end{tabular}

Note: All coefficients greater than 0.18 and 0.15 are significant at $P<0.01$ and $<0.05$, respectively. 
Table 2 Results of analyses on hypothesized relationships

Hypothesized relationships
Standardized

coefficient

H1 In the born-global firm, global technological competence is a function of:
(a) international entrepreneurial orientation
0.28
$S$

(b) international marketing orientation

0.13

NS

H2 In the born-global firm, unique products development is a function of:

(a) international entrepreneurial orientation

0.19

0.24

$S$

(b) international marketing orientation

0.23

0.35

$S$

(a) international entrepreneurial orientation

(b) international marketing orientation

$S$

H4 In the born-global firm, leveraging foreign distributor competences is a function of:

(a) international entrepreneurial orientation

$0.10 \quad$ NS

(b) international marketing orientation

0.26

H5 In the born-global firm, performance in international markets is a function of:
(a) global technological competence
(b) unique products development
(c) quality focus
(d) leveraging foreign distributor competences

0.21

0.14

0.30

0.18

Notes: All standardized coefficients greater than 0.18 and 0.13 are significant at $P<0.01$ and $<0.05$ respectively.

$\mathrm{S}=$ supported; $\mathrm{NS}=$ not significant.

orientation and global technological competence was not significant. Findings also suggest that unique products development and quality focus are both significantly $(P<0.01)$ driven by international entrepreneurial orientation and international marketing orientation, supporting $\mathrm{H} 2$ and H3. In addition, although results suggest that leveraging foreign distributor competences is a significant $(P<0.01)$ function of international marketing orientation, partially supporting $\mathrm{H} 4$, the linkage posited between international entrepreneurial orientation and leveraging foreign distributor competences in $\mathrm{H} 4$ was not significant. Findings also provide evidence that global technological competence, unique products development, quality focus, and leveraging foreign distributor competences are all significant $(P<0.05)$ drivers of performance in international markets in bornglobal firms, supporting H5. Finally, as suggested earlier, Table 1 indicates that global technological competence is correlated with unique products development, and leveraging foreign distributor competences is correlated with both unique products development and quality focus. In all, results of the survey-based study generally confirm the case studies and support the critical importance of organizational capabilities, as applied here to bornglobal firms.

\section{Discussion}

Cast in an evolutionary economics (Nelson and Winter, 1982) framework, our findings imply that the strongly innovative nature of born-global firms supports these businesses in developing particular types of knowledge, which drives the development of organizational capabilities that support early internationalization and superior performance in diverse international markets. Innovative activities in these firms support the opening of new markets and reinvention of the firm's operations to serve those markets optimally. Our findings also revealed and confirmed the importance of specific key organizational capabilities that engender international success in born globals. These findings have implications as well for internationalizing smaller firms in general. Born globals are young businesses characterized by a particular pattern of innovativeness that gives rise to early internationalization. Thus our investigation also contributes to the innovation literature by linking innovation to the phenomenon of early adoption of internationalization. 
The resource-based perspective emphasizes that the firm's foundational resources are particularly important in diverse business environments because they provide a stable basis for strategy development. Knowledge possessed by born globals appears to be a critical resource in this process. Managers in young, internationally oriented firms should develop knowledge that is both relatively unique and inimitable, in order to maximize its utility for superior international performance. Knowledge generates appropriate organizational capabilities that become embedded into the firm's cultures via ongoing replication of routines, producing a unique configuration of resources.

Young and small firms normally endure a scarcity of financial, human, and tangible resources that results in a reduced set of competitive options. Historically, substantial international business activities were beyond the reach of such firms. However, relatively recent advances in information, communications, production, and logistics technologies, as well as the emergence of other useful infrastructures and conditions associated with the globalization phenomenon, have given rise to a business environment in which young, smaller firms can participate actively in global markets. Although born globals undoubtedly existed in the past, especially in nations with small domestic markets, contemporary scholars and practitioners are witnessing the widespread emergence of countless such businesses throughout the world.

Despite this, there are perhaps millions of other young and smaller firms that are not international, appear to have little or no international aspirations, and continue to operate strictly within their own domestic markets. It is likely, therefore, that emergent globalization and high technology trends, while necessary, are insufficient to account for the widespread emergence of born globals. In light of the theoretical and empirical results presented here, it appears that, in addition to the presence of facilitating environmental factors, firms must possess specific knowledge-based internal organizational capabilities that support both early internationalization and subsequent success in foreign markets. We have highlighted these capabilities and confirmed their explanatory value in born globals. Moreover, we underscore the role of youth and smaller size, which confer a degree of flexibility and agility that appears to help these businesses succeed abroad. This flexibility is characteristic of young firms that lack the adminis- trative heritage of large, older competitors. The absence of a firmly embedded infrastructure and managerial mindset facilitates early and rapid internationalization.

At the organizational culture level, international entrepreneurial orientation reflects an innovationfocused managerial mindset that appears to lead born globals to pursue a collection of strategies aimed at maximizing international performance. Our findings imply that international entrepreneurial orientation may be especially important to these firms because it appears to drive them to develop high-quality goods that are distinctive and technologically advanced, and which are associated, in turn, with born-global international success.

Like international entrepreneurial orientation, international marketing orientation is also particularly relevant to born globals and appears to engender specific innovation-based strategies that in turn drive superior international performance. This arises within a multi-country context that imposes numerous uncontrollable and often unique challenges on born-global managers. Their international marketing orientation facilitates knowledge of customers, product development and adaptation, as well as meticulous manipulation of key marketing tactical elements to target foreign customers with quality, differentiated goods.

Limited resources imply that born globals must succeed in foreign markets earlier, and with superior efficiency and effectiveness. International performance and the ultimate survival of the firm appear to hinge on well-conceived manipulation of strategic variables. International entrepreneurial and marketing orientations are particularly important to born globals because, owing to limited traditional resources, they cannot afford to make the mistakes that have afflicted the internationalization of other firms.

At the strategy level, global technological competence, unique products development, quality focus, and leveraging foreign distributor competences all appear to be significant drivers of superior performance overseas. Leveraging quality and technological excellence helps born globals to develop offerings that appeal to niche markets around the world. The finding is consistent with research in Australia (Rennie, 1993), which found that early exporters thrive by leveraging proprietary technologies and high-quality goods. The combined, significant roles of global technological competence, unique products development, and quality 
focus provide further evidence that organizational activities related to innovation, $R \& D$, knowledge development, and capabilities leveraging play important roles in positioning born globals for international success. These are all critical activities in the development or positioning of the firm's product offerings. Having relatively unique products can also allow born globals to achieve a sort of 'monopolistic advantage' (Hymer, 1976) that further supports international success. The literature specifies numerous approaches for achieving international business success, but innovative processes that drive the development of superior, unique products appear particularly important to born-global success.

Strong relationships that born globals develop with competent foreign distributors also help pave the way for superior performance abroad. Descriptive measures reveal that the randomly chosen born globals in our study are targeting their goods to a median of 20 countries worldwide. Given the limited traditional resources of these young firms, and the tendency of many to internationalize via exporting, leveraging strong foreign distributors is a key strategy. Foreign distributors provide local advantages related not only to downstream international business activities, but also to gathering market intelligence, forging links with key foreign contacts, deepening relations within extant markets, and cultivating new buyer segments.

\section{Conclusion}

Among the firms examined here, youth and lack of experience, as well as paucity of financial, human, and tangible resources, are no longer major impediments to the large-scale internationalization and global success of the firm. Companies that possess the characteristics and capabilities described in this study can and do internationalize early, and succeed in international markets. Managers at born globals begin with a global vision, and devise a collection of capabilities at the strategy and organizational-culture levels of the firm that give rise to early adoption of internationalization and success in a broad range of foreign markets. Born globals acquire a substantial, fundamental base of international experience and knowledge that traditional MNEs typically have taken longer to acquire. In this sense, born globals pose an important new challenge to traditional views on the internationalization of the firm.
During the past couple of decades, the volume of global business activity has increased dramatically, and is associated with the emergence of mechanisms and infrastructures that are facilitating the internationalization of countless smaller, entrepreneurial firms. The trend has been hastened by the development of technologies that allow companies to internationalize and conduct global business much more efficiently than ever before. Electronic interconnectedness in particular is driving the emergence of a borderless global economy. Information technology and the Internet are liberating forces, permanently altering the landscape of international trade. Absent the burden of administrative heritage, younger, smaller firms are playing a much greater role in international trade than ever before.

Accordingly, the traditional view of the large multinational corporation as the dominant international form might well be evolving. Born globals are emerging in substantial numbers worldwide, and likely reflect an emergent paradigm, with the potential to become a leading species in the ecosystem of international trade. In this sense, the born-global phenomenon is heartening because it implies the emergence of an international exchange system in which any firm, regardless of age, experience, and tangible resources, can be an active international business participant. Although large global corporations and the negative aspects of globalization often dominate reports in the popular press with respect to the emergent world order, the increasing role of born globals implies a more optimistic view. In relative terms, born globals might be seen to herald a more diverse international business system in which any firm can succeed internationally. Future research should aim at deepening our understanding of early adopters of internationalization, which represent a widespread, ongoing trend.

\section{Acknowledgements}

We thank Tomas Hult, Peter Liesch, Tage Madsen, Benjamin Oviatt, two JIBS reviewers, and Arie Lewin, JIBS Editor-in-Chief, for their insightful and constructive suggestions in developing this manuscript. Financial support from the Center for International Business Education and Research, Michigan State University, in the completion of this research is gratefully acknowledged. 


\section{References}

Aaker, D. and Jacobson, R. (1994) 'The financial information content of perceived quality', Journal of Marketing Research 31(2): 191-201.

Albaum, G. and Peterson, R.A. (1984) 'Empirical research in international marketing: 1976-82', Journal of International Business Studies 15(Spring/Summer): 161-173.

Armstrong, J.S. and Overton, T.S. (1977) 'Estimating nonresponse bias in mail surveys', Journal of Marketing Research 14(3): 396-402.

Autio, E., Sapienza, H. and Almeida, J. (2000) 'Effects of age at entry, knowledge intensity, and imitability on international growth', Academy of Management Journal 43(5): 909-924.

Barkema, H. and Vermeulen, F. (1998) 'International expansion through start-up or acquisition: a learning perspective', Academy of Management Journal 41(1): 7-26.

Barney, J. (1991) 'Firm resources and sustained competitive advantage', Journal of Management 17(1): 99-120.

Bowersox, D. and Cooper, M.B. (1992) Strategic Marketing Channel Management, McGraw-Hill: New York.

Buckley, P.J. and Casson, M.C. (1998) 'Models of the multinational enterprise', Journal of International Business Studies 29(1): 21-44.

Buzzell, R. and Gale, B. (1987) The PIMS Principles: Linking Strategy to Performance, The Free Press: New York.

Casson, M. (2000) Economics of International Business, Edward Elgar: Cheltenham.

Cavusgil, S.T. and Zou, S. (1994) 'Marketing strategy-performance relationship: an investigation of the empirical link in export market ventures', Journal of Marketing 58(1): $1-21$.

Cavusgil, S.T., Zou, S. and Naidu, G.M. (1993) 'Product and promotion adaptation in export ventures: an empirical investigation', Journal of International Business Studies 24(3): 479-506.

Clark, K. (1987) 'Investment in New Technology and Competitive Advantage', in D. Teece (ed.) The Competitive Challenge: Strategies for Industrial Innovation and Renewal, Ballinger: Cambridge, MA. pp. 59-81

Cohen, W. and Levinthal, D. (1990) 'Absorptive capacity: a new perspective on learning and innovation', Administrative Science Quarterly 35(1): 128-152.

Collis, D. (1991) 'A resource-based analysis of global competition', Strategic Management Journal 12(Summer, Special Issue): 49-68.

Conner, K. and Prahalad, C.K. (1996) 'A resource-based theory of the firm: knowledge versus opportunism', Organization Science 7(5): 477-501.

Covin, J. and Slevin, D. (1989) 'Strategic management of small firms in hostile and benign environments', Strategic Management Journal 10(1): 75-87.

Daniels, J. and Radebaugh, L. (1998) International Business: Environments and Operations, 8th edn. Addison-Wesley: Reading, MA.

Deming, W.E. (1982) Quality, Productivity, and Competitive Position, MIT Center for Advanced Engineering Study: Boston, MA.

Dess, G., Lumpkin, G. and Covin, J. (1997) 'Entrepreneurial strategy making and firm performance: tests of contingency and configurational models', Strategic Management Journal 18(1): 2-23.

Dierickx, I. and Cool, K. (1989) 'Asset stock accumulation and sustainability of competitive advantage', Management Science 35(12): 1504-1510.

Dosi, G. (1988) 'Sources, procedures, and microeconomic effects of innovation', Journal of Economic Literature 26(3): $1120-1171$.

Fornell, C. and Larcker, D.F. (1981) 'Evaluating structural equation models with unobservable variables and measurement errors', Journal of Marketing Research 18(1): $39-50$.
Fowler, F. (1988) Survey Research Methods, Sage: Newbury Park, CA.

Gerbing, D. and Anderson, J. (1988) 'An updated paradigm for scale development incorporating unidimensionality and its assessment', Journal of Marketing Research 25(2): 186-192.

Gerbing, D. and Anderson, J. (1992) 'Monte Carlo evaluations of goodness-of-fit indices for structural equation models', Sociological Methods and Research 21(November): 132-160.

Grant, R.M. (1991) 'The resource-based theory of competitive advantage: implications for strategy formulation', California Management Review 33(3): 114-135.

Grant, R.M. (1996a) 'Prospering in dynamically competitive environments: organizational capability as knowledge integration', Organization Science 7(4): 375-387.

Grant, R.M. (1996b) 'Toward a knowledge-based theory of the Firm', Strategic Management Journal 17(December): 109-122.

Hymer, S. (1976) The International Operations of National Firms, MIT Press: Cambridge, MA.

Johanson, J. and Vahlne, J. (1977) 'The internationalization process of the firm: a model of knowledge development and increasing foreign commitments', Journal of International Business Studies 8(1): 23-32.

Joreskog, K. and Sorbom, D. (1997) LISREL 8: A Guide to the Program and Applications, SPSS Inc.: Chicago, IL.

Joreskog, K., Dag, S., Stephen, D.T. and Mathilda, D.T. (2000) LISREL 8: New Statistical Features, Scientific Software International: Lincolnwood, IL.

Khandwalla, P. (1977) The Design of Organizations, Harcourt Brace Jovanovich: New York.

Knight, G.A. and Cavusgil, S.T. (1996) 'The Born Global Firm: A Challenge to Traditional Internationalization Theory', in S.T. Cavusgil and T. Madsen (eds.) Advances in International Marketing, Vol. 8 JAl Press: Greenwich, CT. pp. 11-26.

Kogut, B. and Zander, U. (1993) 'Knowledge of the firm and the evolutionary theory of the multinational corporation', Journal of International Business Studies 24(4): 625-645.

Kotabe, M. (1990) 'Corporate product policy and innovative behavior of European and Japanese multinationals: an empirical investigation', Journal of Marketing 54(2): 19-33.

Leonard-Barton, D. (1992) 'Core capabilities and core rigidities: a paradox in managing new product development', Strategic Management Journal 13: 111-126.

Lewin, A.Y. and Massini, S. (2003) 'Knowledge Creation and Organizational Capabilities of Innovating and Imitating Firms', in H. Tsoukas and N. Mylonopoulos (eds.) Organizations as Knowledge Systems, Palgrave: Basingstoke.

Lumpkin, G.T. and Dess, D. (1996) 'Clarifying the entrepreneurial orientation construct and linking it to performance', Academy of Management Review 21(1): 135-172.

Luo, Y. (2000) 'Dynamic capabilities in international expansion', Journal of World Business 35(4): 355-378.

Massini, S., Lewin, A.Y. and Greve, H.E. (2003) 'Innovators and imitators: organizational reference groups and adoption of organizational routines', (unpublished manuscript).

McDougall, P. and Oviatt, B. (2000) 'International entrepreneurship: the intersection of two research paths', Academy of Management Journal 43(5): 902-906.

McDougall, P., Shane, S. and Oviatt, B. (1994) 'Explaining the formation of international new ventures: the limits of theories from international business research', Journal of Business Venturing 9(6): 469-487.

McGuinness, N., Campbell, N. and Leontiades, J. (1991) 'Selling machinery to China: Chinese perceptions of strategies and relationships', Journal of International Business Studies 22(2): 187-207.

McKee, D., Jeffery, C., Rajan Varadarajan P. and Michael, M. (1992) 'Success-producer and failure-preventer marketing skills: a social learning theory interpretation', Journal of the Academy of Marketing Science 20(1): 17-26. 
Miles, R.E. and Snow, C.C. (1978) Organizational Strategy, Structure, and Process, McGraw-Hill: New York.

Miller, D. (1988) 'Relating Porter's business strategies to environment and structure: analysis and performance implications', Academy of Management Journal 31(2): 280-308.

Miller, D. and Friesen, P.H. (1984) Organizations: A Quantum View, Prentice Hall: Englewood Cliffs, NJ.

Mintzberg, H. (1973) The Nature of Managerial Work, Harper \& Row: New York.

Moen, O. and Servais, P. (2002) 'Born global or gradual global? Examining the export behavior of small and medium-sized enterprises', Journal of International Marketing 10(3): 49-72.

Mohr-Jackson, I. (1998) 'Conceptualizing total quality orientation', European Journal of Marketing 32(1/2): 13-22.

Mortanges, C.P. and Vossen, J. (1999) 'Mechanisms to control the marketing activities of foreign distributors', International Business Review 8(1): 75-97.

Nelson, R. and Winter, S. (1982) An Evolutionary Theory of Economic Change, Belknap Press: Cambridge, MA.

Nikkei Sangyoo Shimbun (1995) Benchaa Shin Sedai (New Generation Ventures), Nihon Keizai Shimbun: Tokyo.

Nonaka, I. (1994) 'A dynamic theory of organizational knowledge creation', Organization Science 5(1): 14-37.

Nunnally, I.C. (1978) Psychometric Theory, McGraw-Hill: New York.

OECD (1997) Globalization and Small and Medium Enterprises (SMES), Organization for Economic Cooperation and Development: Paris.

Oviatt, B. and McDougall, P. (1994) 'Toward a theory of international new ventures', Journal of International Business Studies 25(1): 45-64.

Peng, M. and York, A. (2001) 'Behind intermediary performance in export trade: transactions, agents, and resources', Journal of International Business Studies 32(2): 327-346.

Penrose, E. (1959) The Theory of the Growth of the Firm, Basil Blackwell: London.

Polanyi, M. (1966) The Tacit Dimension, Routledge \& Kegan Paul: London.

Porter, M.E. (1980) Competitive Strategy, The Free Press: New York.

Prahalad, C.K. and Hamel, G. (1990) 'The core competence of the corporation', Harvard Business Review 68(3): 79-91.

Rennie, M. (1993) 'Born global', McKinsey Quarterly (4): 45-52.

Rosson, P. and Ford, I.D. (1982) 'Manufacturer-overseas distributor relations and export performance', Journal of International Business Studies 13(2): 57-72.

Roth, K. and Morrison, A. (1992) 'Business-level competitive strategy: a contingency link to internationalization', Journal of Management 18(3): 473-487.

Rumelt, R.P. (1984) 'Towards a Strategic Theory of the Firm', in R.B. Lamb (ed.) Competitive Strategic Management, Prentice Hall: Englewood Cliffs, NJ. pp. 131-145.

Schumpeter, J. (1934) The Theory of Economic Development, Cambridge University Press: Cambridge.

Schumpeter, J. (1939) Business Cycles, Vol. 1 McGraw-Hill: New York.

Schumpeter, J. (1942) Capitalism, Socialism, and Democracy, Harper \& Brothers Publishers: New York.

Siguaw, J., Simpson, P. and Baker, T. (1998) 'Effects of supplier market orientation on distributor market orientation and the channel relationship: the distributor perspective', Journal of Marketing 62(3): 99-111.

Simmonds, K. and Smith, H. (1968) 'The first export order: a marketing innovation', British Journal of Marketing 2(Summer): 93-100.

Simon, H. (1996) Hidden Champions: Lessons from 500 of the World's Best Unknown Companies, Harvard Business School Press: Boston.

Slater, S. and Narver, J. (1992) Superior Customer Value and Business Performance: The Strong Evidence for a MarketDriven Culture, Marketing Science Institute: Cambridge, MA, pp. 92-125.
Smith, W. (1956) 'Product differentiation and market segmentation as alternative marketing strategies', Journal of Marketing 21(July): 3-8.

Solow, R.M. (1957) 'Technical change and the aggregate production function', The Review of Economics and Statistics 39(February): 312-320.

Steensma, H.K., Marino, L., Weaver, K.M. and Dickson, P. (2000) 'The influence of national culture on the formation of technology alliances by entrepreneurial firms', Academy of Management Journal 43(5): 951-973.

Szymanski, D., Bharadwaj, S. and Varadarajan, P.R. (1993) 'Standardization versus adaptation of international marketing strategy: an empirical investigation', Journal of Marketing 57(4): 1-17.

Teece, D. and Pisano, G. (1994) 'The dynamic capabilities of firms: an introduction', Industrial and Corporate Change 3(3): 537-556.

Teece, D., Pisano, G. and Shuen, A. (1997) 'Dynamic capabilities and strategic management', Strategic Management Journal 18(7): 509-533.

Utterback, J.M. and Abernathy, W.J. (1975) 'A dynamic model of process and product innovation', Omega 3(6): 639-656.

Wernerfelt, B. (1984) 'A resource-based view of the firm', Strategic Management Journal 5(2): 171-180.

Young, S., Bell, I. and Crick, D. (2000) 'The Resource-based Perspective and Small Firm Internationalization: An Exploratory Approach', in C. Millar, R. Grant and C. Choi (eds.) International Business: Emerging Issues and Emerging Markets, St Martin's Press: New York.

Zahra, S., Ireland, R. and Hitt, M. (2000) 'International expansion by new venture firms: international diversity, mode of market entry, technological learning, and performance', Academy of Management Journal 43(5): 925-950.

\section{Appendix: Measurement scales}

Construct (composite reliability, $\mathrm{CR}_{\eta}$ )

Item (standardized coefficient loading from CFA analyses in LISREL8)

(Source)

\section{International entrepreneurial orientation $\left(\mathrm{CR}_{\eta}=\mathbf{0 . 8 0}\right)$}

Top management tends to see the world, instead of just the USA, as our firm's marketplace (0.92)

The prevailing organizational culture at our firm (management's collective value system) is conducive to active exploration of new business opportunities abroad (0.89)

Management continuously communicates its mission to succeed in international markets to firm employees (0.95)

Management develops human and other resources for achieving our goals in international markets (0.89)

Our top management is experienced in international business $(0.73)$

Over the past 5 years, our firm has marketed very many products in foreign markets*

In international markets, our top managers have a proclivity for high-risk projects (with chances for high returns)* 
When confronted with international decisionmaking situations, we typically adopt a cautious, 'wait-and-see' posture in order to minimize the

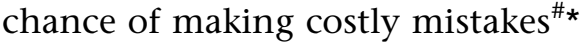

Management communicates information throughout the firm with respect to about our successful and unsuccessful customer experiences abroad*

Management believes that, owing to the nature of the international business environment, it is best to explore it gradually via conservative, incremental steps $^{\# *}$

Top management is willing to go to great lengths to make our products succeed in foreign markets*

Vision and drive of top management are important in our decision to enter foreign markets*

(Covin and Slevin, 1989; Khandwalla, 1977; Miller and Friesen, 1984)

\section{International marketing oirientation $\left(\mathrm{CR}_{\eta}=\mathbf{0 . 8 5}\right)$}

(In international markets, own firm rating relative to main competitors; $1=$ much worse than main competitors; $7=$ much better than main competitors)

Knowledge of customers and competitors (0.80)

Marketing planning process $(0.82)$

Development or adaptation of the product $(0.68)$

Effectiveness of pricing (0.62)

Advertising effectiveness (0.70)

Effectiveness of distribution (0.77)

Image of your firm $(0.88)$

Locations of sales outlets*

Ability to work well with distributors*

Ability to respond quickly to developing opportunities*

Skill to target and segment individual markets*

Ability to use marketing tools (product design, pricing, advertising, etc.) to differentiate this product $(0.81)$

Control and evaluation of marketing activities (0.80)

(Adapted from McKee et al., 1992)

\section{Global technological competence $\left(\mathrm{CR}_{\eta}=\mathbf{0 . 7 2}\right)$}

Our firm is at the leading technological edge of our industry in this market $(0.75)$

We invented a lot of the technology imbedded in this product $(0.94)$

Compared with local competitors, we're often first to introduce product innovations or new operating approaches $(0.91)$

We are recognized in our main export market for products that are technologically superior*
Our firm is highly regarded for its technical expertise among our channel members in this market*

In the design and manufacture of this product, we employ some of the most skilled specialists in the industry*

\section{Unique products development $\left(\mathrm{CR}_{\eta}=\mathbf{0 . 7 8}\right)$}

Our primary export product caters to a specialized need that is difficult for our competitors to match (0.88)

In our industry, this product represents a new, innovative approach to addressing the customer's basic need $(0.85)$

Compared with our main competitors' offerings, this product is unique with respect to design $(0.81)$

Compared with our main competitors' offerings, this product is unique with respect to technology (0.97)

Compared with our main competitors' offerings, this product is unique with respect to performance $(0.75)$

(Miller, 1988; Porter, 1980; Roth and Morrison, 1992)

\section{Quality focus $\left(\mathrm{CR}_{\eta}=\mathbf{0 . 7 2}\right)$}

Emphasizing quality customer service is important to our firm's strategy in this market (0.46)

Emphasizing product quality is important to our firm's strategy in this market (0.41)

For us, success in this market is driven by truly satisfying the needs of our customers there (0.59)

The performance of this product truly meets the expectations of customers in this market (0.53)

The service and support provided with this product truly meet the expectations of customers in this market (0.79)

(Buzzell and Gale, 1987)

\section{Leveraging foreign distributor competences $\left(\mathrm{CR}_{\eta}=\mathbf{0 . 9 2}\right)$}

(Extent to which foreign distributor meets expectations with respect to the following; $1=$ falls very short of expectations; $7=$ meets expectations very well)

Setting local prices $(0.78)$

Local selling (0.93)

Local advertising (0.98)

After-sales service (0.89)

Collecting local market information (0.72)

Liaison with local government (0.79)

Cultivating new business/expansion (0.81)

Product modification (if any)* 
Arranging international shipping*

Arranging local shipping*

Local public relations*

Customer technical support/training*

Translation of sales literature, usage instructions, or labels*

(Adapted from McKee et al., 1992; Daniels and Radebaugh, 1998)

Performance in international markets $\left(\mathrm{CR}_{\eta}=\mathbf{0 . 8 6}\right)$ ( $1=$ very unsatisfied; $7=$ very satisfied $)$

Relative to prior expectations, how satisfied have you been over past 3 years with product's performance regarding:

Market share in this market $(0.87)$

Sales growth in this market $(0.85)$

Pre-tax profitability in this market $(0.97)$

Compared with your main competitor(s), sales growth of this product in its main export market

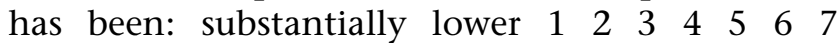
substantially higher (0.78)

On a scale from 1 to 10 , how would you rate the success of this product in its main export-market over the past 3 years? unsuccessful 1.10 successful (0.92)

Gaining new knowledge/technology in this market*

Compared with your domestic business, the total return on your investment (ROI) of this product in its main export market has been. . . substantially lower 1234567 substantially higher*

(Adapted from Cavusgil and Zou, 1994)

\section{Notes}

Except as noted, a seven-point ordinal scale was used where $1=$ not at all and $7=$ to an extreme extent.
All standardized coefficient loadings are significant at $P<0.01$.

*Indicates item that was dropped in the scale purification process.

"Indicates reverse-polarity item.

\section{About the authors}

Gary A Knight is Associate Professor of Marketing and Director of International Business Programs at Florida State University (FSU). His research focuses on international entrepreneurship, international marketing strategy, and internationalization in the SME. He is the author of more than 60 refereed conference and journal articles. He has lectured in numerous countries worldwide, and launched FSU's international business programs in London, Paris, Tokyo, and Valencia, Spain. He received his Ph.D. at Michigan State University.

S Tamer Cavusgil is University Distinguished Faculty and The John W Byington Endowed Chair in Global Marketing at Michigan State University. Professor Cavusgil specializes in international marketing strategy, early internationalization, and export trade policy. $\mathrm{He}$ is the author of several books and over 100 refereed articles. Doing Business in Emerging Markets (Sage Publications, 2002) is his most recent contribution. Cavusgil is the Associate Editor-in Chief, Journal of International Business Studies, and Editor of Elsevier book series, Advances in International Marketing. He also serves on the editorial review boards of over a dozen professional publications. 